\title{
Green building, split-incentives and affordable rental housing policy
}

\author{
Stefen MacAskill ${ }^{a, b, c}$ (D), Rodney A. Stewart ${ }^{a, c}$, Eduardo Roca ${ }^{a, b}$, Benjamin Liu ${ }^{a, b}$ \\ and Oz Sahin ${ }^{\mathrm{a}, \mathrm{c}}$ (D) \\ ${ }^{a}$ Cities Research Institute, Griffith University, Brisbane, Australia; ${ }^{b}$ Department of Accounting, Finance \\ and Economics, Griffith Business School, Griffith University, Brisbane, Australia; ' $S$ School of \\ Engineering and Built Environment, Griffith University, Brisbane, Australia
}

\begin{abstract}
We investigate the notion of capitalizing on investments in energy, water and gas efficiency within the context of affordable rental housing subsidy schemes; how associated utility savings offer a means to deliver policy designed to mitigate for issues of split-incentives. An Australian case study representing a typical affordable housing development is analyzed for two scenarios - a 'Business as usual' and 'Green-certified' case. Over a 10-year rental tenancy, operational utility efficiencies, achieved through green building principles are modelled to reduce total housing costs by 1.7-3.8\% (AUD \$5-18 per week), for one- and four-person households, respectively. Over the building lifecycle, the net present value of improvements are forecasted to be positive, signalling favourable support for policy interventions. The findings provide evidence to support a broader notion of 'housing assistance' to one that includes improved standards on residential utility efficiency. We present three policy options on how to deliver these benefits to stakeholders.
\end{abstract}

\section{ARTICLE HISTORY}

Received 2 November 2018

Accepted 4 October 2019

\section{KEYWORDS}

Affordable housing policy; green building; national rental affordability scheme; split-incentives; principalagent theory

\section{Introduction}

Defining 'Affordable housing' (AH) is often misconstrued under several guises; subjective by definition, and with differing perspectives between countries and regions. In Australia, there is the broad agreement that housing is considered 'affordable' when it does not constitute more than $30 \%$ of household income (National Housing Strategy, 1992). 'Housing stress' can be attributed to those lowincome households that spend more than $30 \%$ of their gross income on accommodation (Yates, 2008). Presently (2018), over 45\% of Australian low-income households (those in the bottom two income quintiles) are facing housing stress (ABS, 2018). Public sector funding for social housing has declined in many countries; hence, the

CONTACT Oz Sahin o.sahin@griffith.edu.au E Cities Research Institute \& Griffith School of Engineering and Built Environment, Griffith University, Brisbane, Australia

(4) Supplemental data for this article can be accessed at https://doi.org/10.1080/02673037.2019.1677861.

(C) 2019 Informa UK Limited, trading as Taylor \& Francis Group 
private rental sector is playing an increasingly important role in access to affordable housing options (Pero et al., 2016).

Internationally, a patchwork of housing affordability schemes have been deployed to assist low and middle-income rental households (Pero et al., 2016). These have included a range of demand ${ }^{1}$ and supply-side ${ }^{2}$ subsidies in an effort to increase $\mathrm{AH}$ options and reduce the financial burden of rental housing costs. In Australia, for example, the 'National Rental Affordability Scheme' (NRAS) was introduced in 2008 to deliver affordable rental housing options to low- and middle-income households, via a supply-side subsidy. Investors in the scheme deliver rental units that are required be rented at a $20 \%$ discount to market rent to eligible households. In exchange, investors benefit from an annual financial incentive ${ }^{3}$ over a fixed 10-year period, with the aim to deliver a favourable net return. However, contrary effects such as escalating utility costs detract from the aims of these policies; for instance, domestic residential energy costs have increased 63\% during the 2007-2017 period (ACCC, 2017). Gas and water costs have followed similar trajectories. These price increases exert increasing pressure on rental households' bottom line and detract from policy objectives.

By metrics of 'housing stress', low-income rental households spend a greater proportion of their gross income on utility-related housing expenses (Wilkins \& Inga, 2018). Rental households often suffer from issues of 'split-incentives'; a well-known principal-agent problem within rational choice economics. As Bird \& Hernández (2012) describe, agency problems refer to any situation in which a principal pays an agent for a service or good. The theory demonstrates that principals (tenants) often have different goals and information than an agent (investors) who supplies them with goods or services. The split-incentive problem highlights the opposing goals between principal and agent. That is, the principle seeks to minimize housing cost, while the agent seeks to maximize net return on the rental property within the $\mathrm{AH}$ scheme. The principal-agent theory is a valuable approach for understanding problems evident in the split-incentive, particularly those regarding the governmentendowed incentive structures for investors and tenants (Bird \& Hernández, 2012). There is broad consensus that the total cost of ownership of a building should include both the initial capital investment as well as the lifecycle operation and maintenance (O\&M) costs (Islam et al., 2015; Mangold et al., 2018; Morrissey et al., 2013; Morrissey \& Horne, 2011; Shirgaokar \& Rumbach, 2018). It is within this context of the split-incentive issue and government-supported affordable housing policy, we explore how investments into 'Green Building' (GB), and the associated operational utility efficiency improvements, may be used effectively in $\mathrm{AH}$ policy, and how stakeholder outcomes may be affected. This article focuses on the financial implications of integrating GB principles into a typical affordable housing development.

Investments directed towards operational utility efficiency in buildings, and the associated concept of 'Green building' (GB) have emerged as part of a larger social movement towards environmental, social and economic sustainability (Hoffman \& Henn, 2008). Quantitative research into the achievable utility cost savings of residential GB is not a new concept, having previously been undertaken for both retrofitted and new buildings (Berry et al., 2014; Copiello, 2015; Moore et al., 2017). However, 
establishing incontrovertible utility consumption statistics and even the notion of what constitutes a 'green' versus a comparable 'control' or base case building, is idiosyncratic across countries, climate zones, site locations and baseline building codes. A number of studies on green, social and affordable housing have focused on qualitative data, frequently presented in the form of interviews (Boerenfijn et al., 2018; Wrigley \& Crawford, 2017). Additionally, studies have investigated a broader analysis of GB diffusion and GB criteria in AH. Gan et al. (2017) established critical sustainable performance criteria for affordable housing in China (Gan et al., 2017), while Zhang et al. (2018) have investigated the diffusion of green housing in urban China through varying policy instruments (Zhang et al., 2018). More broadly, research into housing affordability and related issues have contributed to research surrounding broader areas of 'social deprivation' which explore a wide range of economic, social and environmental perspectives, including housing policy failure and social inequity, energy poverty, transport costs, and barriers to housing and services (Aimee, 2015; Beer et al., 2007; Berry, 2003; Cai et al., 2013; Cao \& Hickman, 2018; Hamidi et al., 2016; Harrison \& Popke, 2011; MacKillop, 2013). These previous studies provide insightful context into the issues that are contributing factors to the housing affordability 'crisis' (Eslake, 2013). Having said that, there remains a gap in the literature in understanding how investments into GB principles may be used effectively as a form of a demand-side subsidy in $\mathrm{AH}$ policy, and how stakeholder outcomes may be affected.

In market housing, utility efficiency (or GB improvements) has been found to generally be capitalized into the market rent (Walls et al., 2017). Government-led $\mathrm{AH}$ schemes, such as NRAS and other international equivalents, rarely consider the operational utility performance of buildings when assessing the eligibility of $\mathrm{AH}$ development proposals, which, we argue, is a missed opportunity to address issues of split-incentives relating to utility efficiency improvements. Based on this observation, and the gap in literature on this subject, the article provides an answer to the following broad research question:

What are the financial benefits of green building from the perspective of low-income tenants and policy makers, and, what kind of affordable housing policy would enable these benefits to be shared (avoiding split-incentives) among stakeholders in affordable housing?

To analyze this question, an Australian AH case study, in the design stage, is modelled for two scenarios: A 'Business as usual' (BAU), and a 'Green-certified' (termed 'Green building (GB)) case. A 'Green Star Multi Unit Residential' rating of 4 stars is applied as the GB case. Operational utility consumption is forecasted using existing evidence in both scenarios, and utility savings are forecasted over a 10- and 20-year rental tenancy arrangement similar to that offered by the NRAS. Particular emphasis was placed on national and local data for the Brisbane area. This article examines rental housing costs, inclusive of utility costs, and the degree to which GB principles can reduce housing costs. These utility savings are then compared to the additional capital costs or construction cost, called the green premium, to derive the net financial benefits, which are technically calculated using the net present value (NPV) technique. The objective is then for $\mathrm{AH}$ policy to find a way to share these net financial benefits, represented by NPV, among stakeholders in the AH sector. 
The article has been separated into seven main sections. Section 1 has provided a conceptual introduction and context of the article. Sections 2 and 3 focus on a literature review specific to affordable housing policy and GB, respectively. Section 4 introduces the selected case study, the methodology and key data sources for analysis. Results of the case study are included in Section 5. Section 6 provides a discussion of the findings and the relevance to contemporary affordable housing policy. A summary of the article findings and key conclusions are provided in Section 7.

\section{Affordable housing policy}

The term 'affordable housing' has been maturing as a category of its own within housing policy and research circles; although there exists some ambiguity among 'social' and 'affordable' housing definitions. Within rental housing, Czischke \& van Bortel (2018) seek to differentiate these definitions through a continuum; on one side 'social rent', delivering housing fixed to a proportion of household income, and on the other, 'market rent' which is based on demand and supply conditions with no government support. 'Affordable rent' is identified as an intermediary between these two demarcations, where rents are derived from, but lower than, market rent (Czischke \& van Bortel, 2018).

Internationally, provision of affordable housing pathways to low- and middleincome groups differ according to approaches to governance. Broadly, housing assistance schemes can be characterized by demand- and/or supply-side approaches (Berry \& Hall, 2005). Demand-side assistance provides support to low-income tenants, either in the form of cash payments or housing vouchers. Supply-side assistance provides government funding for the expansion of dwelling stock provided at less than market rates to eligible residents (Berry \& Hall, 2005; Oxley, 2012), in many cases through meeting investor yield criteria to attract investment into the scheme. There is a long withstanding debate on which approach is superior (Galster, 1997; Sa-Aadu, 1984), though there is no clear consensus for all contexts. Numerous studies suggest a consideration of both approaches according to local housing market conditions (Jacobs et al., 2015; Sa-Aadu, 1984; Yates \& Whitehead, 1998).

In practice, current demand-side examples include 'Commonwealth Rental Assistance' (CRA) in Australia, 'Housing Benefit' in the United Kingdom, and 'Section 8 housing vouchers' in the United States. These schemes provide financial support to households to meet a portion of housing costs, primarily in the private rental market. However, for some markets, it has been argued that these incentives inflate market rental costs in well-located areas rather than ameliorating fundamental shortages in housing supply. Consequently, this has a detrimental effect on those unsubsidized households that fall outside the housing assistance safety net (Apgar Jr, 1990; Milligan et al., 2009).

In the United States, the 'Low-income Housing Tax Credit' (LIHTC) delivers demand-side support principally through tax incentives to private developers to invest in eligible affordable housing projects. The LIHTC has proven to be an efficient, productive and broadly accepted financing tool for the development, construction, rehabilitation and preservation of privately owned and operated low-income rental 
housing (Rowley et al., 2016). The scheme has faced scrutiny relating to the spatial distribution of developments in areas of high poverty (Dawkins, 2011; Diamond \& McQuade, 2019). Since its inception in 1987, the LIHTC has delivered nearly 3 million affordable housing units (DuBois, 2018).

In Australia, the 'National Rental Affordability Scheme' (NRAS) aims to increase the supply of new and affordable rental dwellings though financial concessions to private or institutional residential property investors for a period of up to 10 years. In exchange, these properties are required to be let to low- and middle-income households that meet the NRAS income threshold at least $20 \%$ below market rates. NRAS eligible households had annual incomes between AUD \$50,489 and \$108,434 for oneand four-person households, respectively (Government Q, 2018). Tenancy leases under NRAS operate similarly to a typical residential lease, where tenants are obliged to pay for all associated housing costs, including ongoing utility expenses. Incentives are provided to suppliers (primarily private property investors) through an annual tax offset certificate, or direct payment scheme. NRAS has issued up to 38,000 incentives since its inception (Government Q, 2018). The scheme has been generally regarded as a success in terms of delivering a supply of new affordable housing options to market; however, it has largely failed to attract substantial institutional investment due to insufficient scale, scheme longevity and consistency (Rowley et al., 2016).

In this article, we focus on supply-side affordable rental housing policies within the context of NRAS as a means to deliver green-certified rental dwellings and mediate for associated issues of split-incentives. However, associated residential utility efficiency through GB is argued to provide a degree of demand-side support.

\section{Green affordable housing}

Green building (GB) terminology is commonly used interchangeably with terms such as sustainable building, high-performance building and sustainable construction. Yudelson (2008) defines GB as: "A high-performance property that considers and reduces its impact on the environment and human health". It is a building that is designed to consume less energy and water, while reducing the lifecycle environmental impact of materials used (Yudelson, 2008). In Australia, the 'Green Star Multi-residential' rating certification focuses on these considerations, in addition to variables such as transport (i.e. connectivity to public transport and cycling facilities), land use and ecological design, among others (GBCA, 2016). There are numerous GB rating systems internationally (i.e. BREAM, LEED, Green Mark, Estidama, GSAS) which broadly follow similar environmental metrics on what it means to be a GB.

A number of international case studies have focused on the viability and profitability of integrating GB principles into typical housing development. These have shown GB principles yielding positive financial results through positive net present value (Verbeeck \& Hens, 2005) and high internal rates of return on efficiency investments (Nikolaidis et al., 2009). The viability of GB principles have been found to be sensitive to marginal changes in input variables (such as discount rates and utility costs) (Zalejska-Jonsson et al., 2012). 
It is a common view that 'green' and 'affordable' construction is an incompatible proposition (Hwang \& Tan, 2012; Issa et al., 2010). However, a review of the literature provides no conclusive empirical evidence to suggest that GB construction must cost more than regular construction (Dwaikat \& Ali, 2016; Rehm \& Ade, 2013). In one reported case, GB standards are found to reduce construction cost by $-0.4 \%$ (Dwaikat \& Ali, 2016). However, the empirical evidence is largely inconclusive, with premiums ranging from approximately $-0.4 \%$ to $21 \%$, varying significantly by region, the type of GB principles deployed and the methodology behind the calculation (McKenna, 2017). It is important to consider how these investments manifest themselves in future values (other than operational efficiencies). International studies suggest that green-certified residential buildings attract a $6.9 \%$ sale price premium on the secondary sales market in China (Zhang et al., 2017). Chegut et al. (2016) found a $6.3 \%$ sale price premium for highly efficient 'A-labelled' AH developments in Denmark (Chegut et al., 2016). These findings are consistent with empirical evidence in US commercial and office green-building statistics, which have found higher rental/sale premiums in addition to higher occupancy rates (Wiley et al., 2010). Moreover, GB have also been found to include a number of possible positive externalities beyond financial returns, such as health and community benefits (GBCA, 2016; $\mathrm{Hu}$ et al., 2014). While sale price premiums are important considerations, we do not seek to model these effects in this article.

GB certification mandates (while desirable) are atypical of mainstream, government-supported affordable housing policy, internationally and within Australia. In the United States, some state-controlled housing finance agencies that are responsible for distributing federal LIHTC incentives favour development applications which focus on superior energy efficiency or GB certification (Huduser, 2018); a form of 'economic incentives for environmental protection' (Oxley, 2004). Reina \& Kontokosta (2017) found that subsidized multifamily housing in the USA is broadly associated with higher utility consumption versus comparable market rate housing (Reina \& Kontokosta, 2017). GB principles, and less commonly, GB certification for $\mathrm{AH}$ developments have been implemented in various 'showcase' projects within Australia and overseas. The 'Hopkins Street' AH development, located in Hobart, Tasmania (rated 5 Green Stars) was able to achieve approximate utility cost reductions for tenants between 25 and 50\% (Chua, 2014). While dwellings within the 'Lochiel Park Green Village' in South Australia were able to cut average energy consumption by more than 50\% (Berry et al., 2014). However, determination of the typically expected benefits of GB is not possible. This study explores the specific potential benefits of GB certification for a project based in Yeronga, Brisbane. Building type, location and use, offer a different basis for comparisons. Business as usual (BAU) performance will vary by climate zone or region; however, there is a general consensus that GB principles will reduce the overall energy, water and gas consumption for tenants.

The literature provides evidence to suggest that investments in utility efficiency of residential building will yield benefits to AH policy (Reina \& Kontokosta, 2017; Schwartz et al., 2018). The benefits of GB are largely understood, however there is much less understanding on how GB affects the 'affordability' of rental housing, 
particularly in the case of Australia. Furthermore, there is limited direction on how GB may be used to enhance AH policy objectives, particularly for those schemes where government-supported financial incentives are in place, towards novel 'Green Affordable Housing' (GAH) policies.

\section{Methodology}

A case study has been used as a basis for the article. Construction design plans were analyzed for a new AH development in Yeronga, Brisbane Australia. NRAS developments are generally new and constructed to a comparable quality respective to surrounding development; therefore, the case study is representative of this typical profile. The objectives of the case study analysis were twofold: (1) to compare the operational utility consumption and cost implications of a 'Green Building' (GB) scenario versus a 'Business as Usual' (BAU) scenario; and (2) to investigate the 'net present value' (NPV) of integrating the GB improvements (in this case, the 'Green Premium' for Green Star certification). Following this analysis, implications as they relate to affordable housing policy are discussed. A systematic process consisting of six main steps is undertaken, shown in Figure 1.

This process has been further defined in the following sections.

\subsection{Case study: Yeronga affordable housing development}

The 'Yeronga AH development' is multi-residential building of 120 one-, two- and three-bedroom units, over a total gross floor area of $8600 \mathrm{~m}^{2}$.

The development is located in Yeronga, Brisbane; a well-connected suburb approximately $5 \mathrm{kms}$ south of the Brisbane $\mathrm{CBD}$. The Brisbane climate is defined as a 'Zone $2^{\prime 4}$ region characterized by warm humid summers and a mild winter. The

\section{Step 1: Case study selection}

\section{Step 2: Collate key data}

BAU Scenario

GB Scenario

Step 2b: Model utility consumption and costs over time

\section{Step 3: Determine tenant utility savings}

\section{Step 4: Calculate the NPV of GB improvements}

\section{Step 5: Discussion of policy recommendations}

Figure 1. Study process highlighting the key steps of the case study and analysis. 


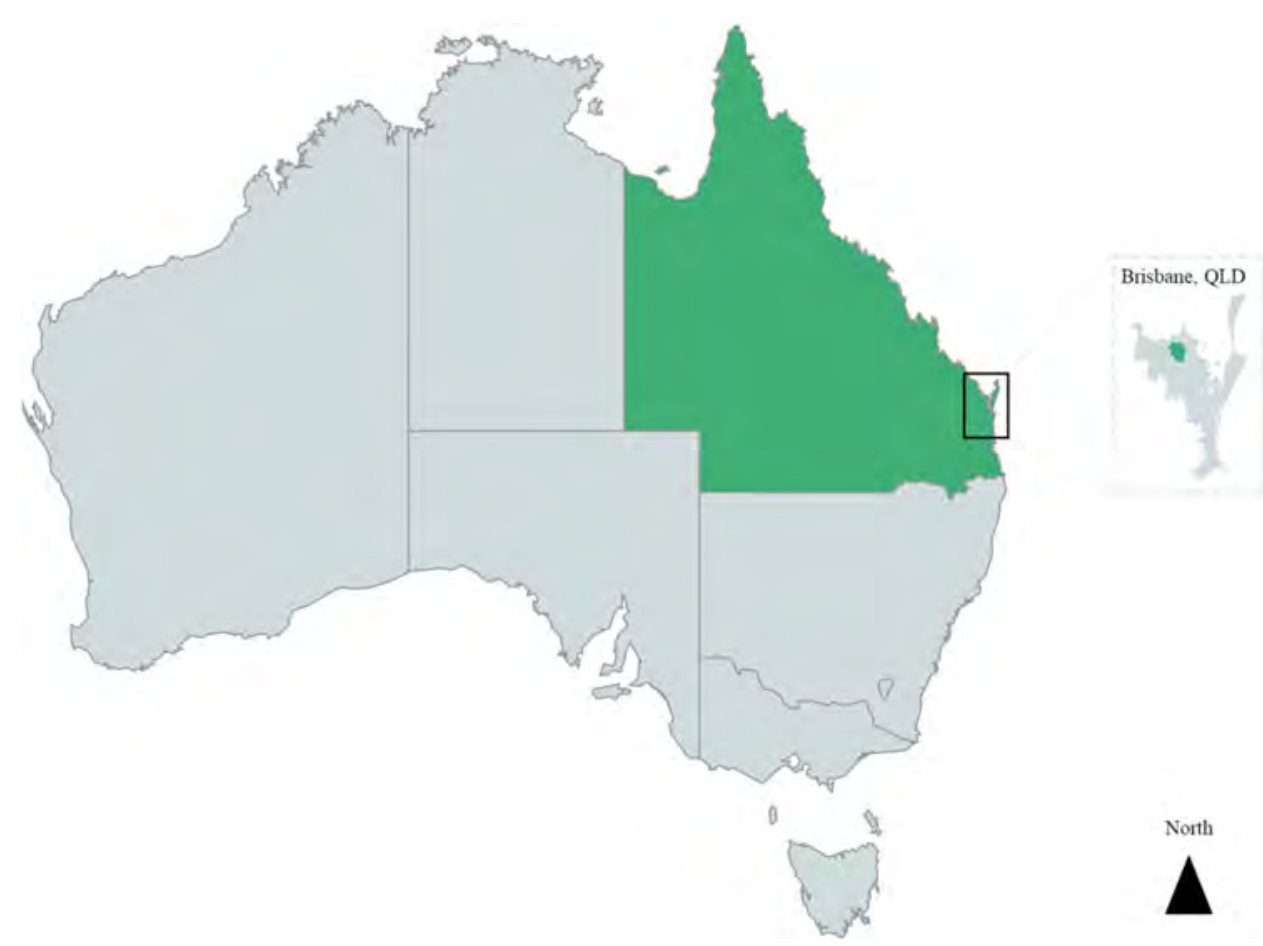

Figure 2. Case study location in South-East Queensland.

case selection is regarded as conservative with regards to GB utility savings due to the temperate climate, with cooler climates of southern Australian cities, such as Melbourne or Sydney, expected to yield larger benefit (Figure 2).

\subsection{Key data sources}

Data collection for the case study was sourced through a comprehensive review of recent industry reports, government statistics and academic literature of comparable case studies of buildings sharing similar use and characteristics, climate zone and building code standards. Assumptions on building characteristics are categorized into a BAU and a GB case. The data selection criteria varied for each 'key data' element, each drawing from relevant sources. These have been summarized in Table 1. A detailed methodology which shaped the final assumptions are provided in detail in the supplementary file.

\subsubsection{Data limitations}

The study attempts to use relevant and informed data for all of the assumptions used as a basis for calculations contained in this article. Where possible, assumptions are supported by reliable databases, and refined ${ }^{5}$ for relevance. However, the results in this study are intended to provide an informed, although indicative estimate on a BAU vs. GB scenario in the Brisbane area.

There is often a mismatch of design and as-built operational performance savings due to a number of factors (i.e. occupant behaviour and envelope performance, 


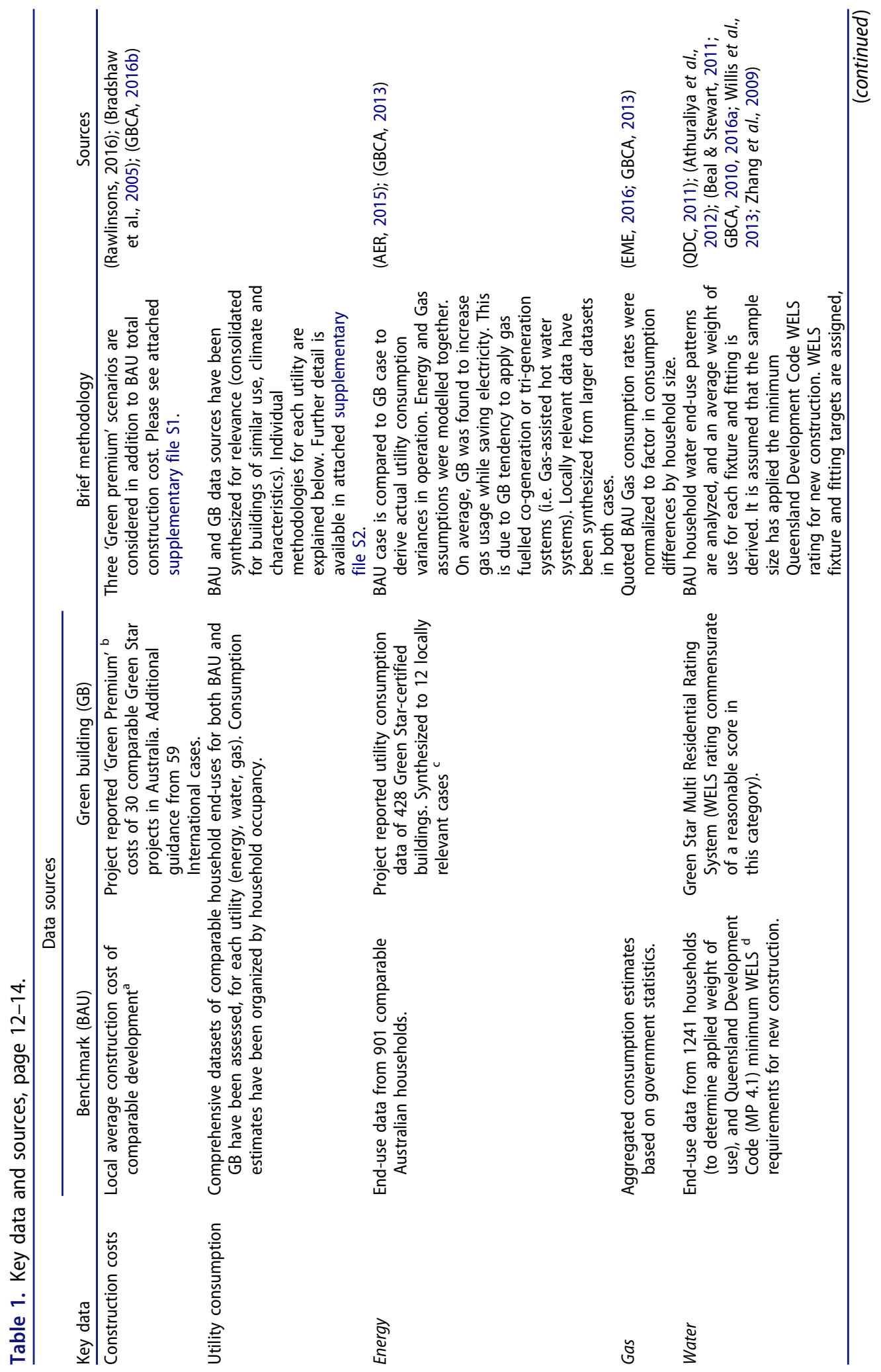




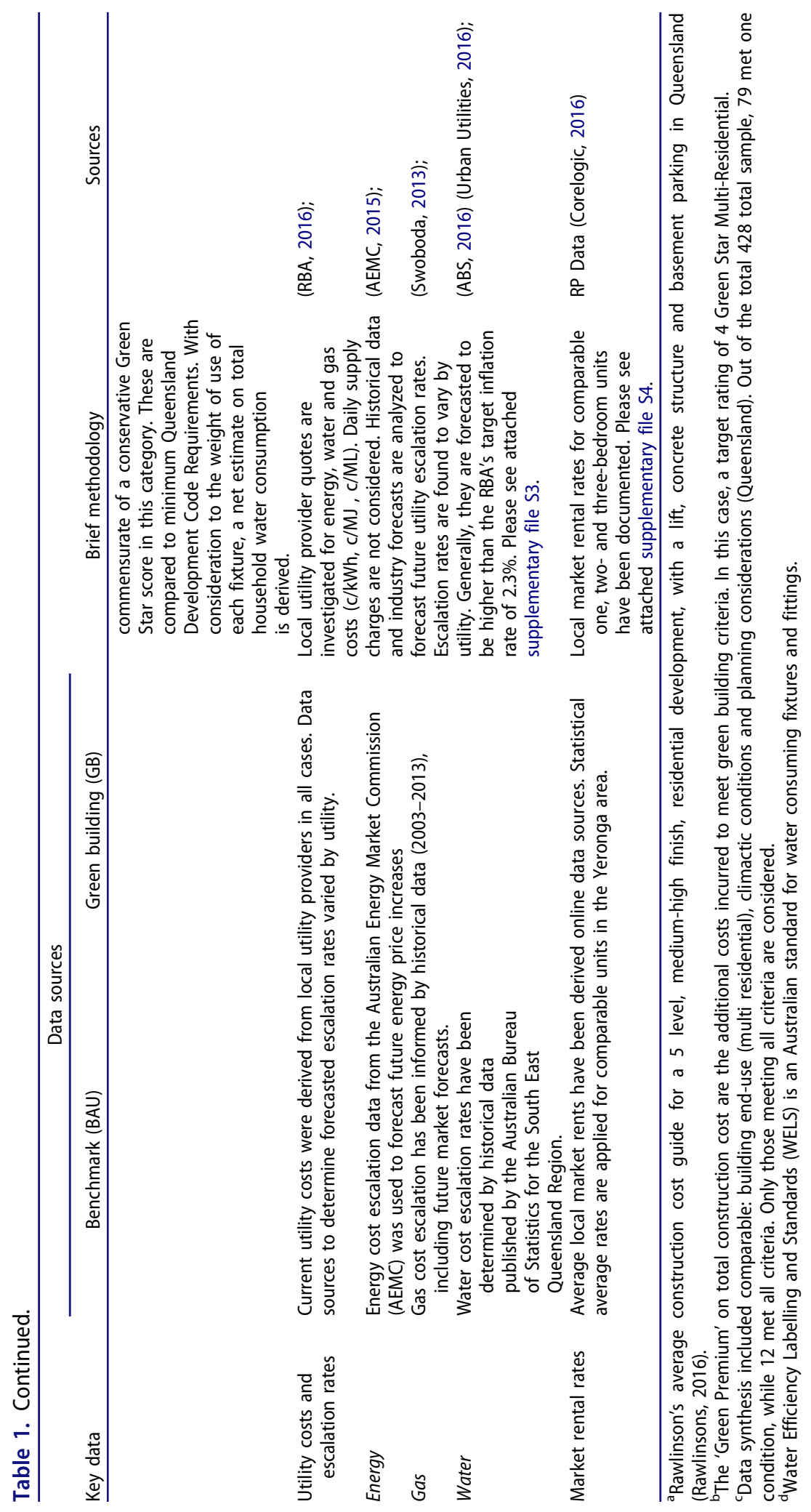


among others). Operational utility savings assumptions were derived from a comprehensive Green Star report whereby GB performance was self-reported, although there a risk of potential bias from the report producer. Operational performance savings differ by climate, local planning requirements and design considerations that determine the 'business as usual' scenario for which savings are based. Additionally, the BAU scenario comprised the average utility consumption data for a large number of households, which included a broad range of ages and construction specifications. Average construction cost and 'green premium' can also differ significantly, depending on measures introduced which are unique to each project. In order to reduce the effects of these data limitations, the study has focused on conservative assumptions, and has applied a sensitivity analysis with the aim to reduce potential data discrepancies.

\section{Results}

\subsection{Tenant savings analysis}

Anticipated tenant utility bills were modelled for BAU and GB scenarios (S5.1 and S5.2 of the supplementary file, respectively). The estimated occupancy period for housing allocations is consistent with the NRAS scheme of 10 years. The purpose of the tenant analysis is to determine the expected utility bill savings, expressed as a total reduction in overall housing costs. Table 2 details the difference between GBand BAU-anticipated utility consumption and cost data (i.e. net annual utility cost savings). Energy, gas and water rates have been escalated using historical data (see S3.2 of the supplementary file).

Utility consumption rates are related to household occupancy, therefore, larger households with more occupants will see a greater net benefit from GB. The analysis suggests that households of all sizes can benefit from the scheme. One-bedroom units with one occupant represent the greatest representation of low-income households in Yeronga. These tenants can perceivably save an average of AUD\$5.05 per week over the course of their tenancy. While seemingly marginal, when savings are aggregated for all 120 units in the development, and considered over the 10-year tenancy contract period, the savings are significant. The largest households (four persons) can save approximately AUD\$17.76 per week.

\subsection{Utility expense and housing cost}

Considering the influence of GB certification further, the annual utility savings as a proportion of market rent was determined, thereby unpacking the total housing affordability outcomes of the various household types and sizes available in the development.

Baseline tenant utility bills are modelled as a function of rental cost. Market rental rates have been escalated according to the CPI, and utility rates escalated accordingly for the 10-year period. Table 3 presents the CPI-adjusted annual market rental rate not considering the inclusion of any government subsidies. Units with a higher occupancy, generally benefit from a greater savings ratio to rent based on typical utility 
Table 2. Expected net annual utility savings per unit configuration (BAU vs. GB).

\begin{tabular}{llllllllllll}
\hline Type & Year 1 & Year 2 & Year 3 & Year 4 & Year 5 & Year 6 & Year 7 & Year 8 & Year 9 & Year 10 & TOTAL \\
\hline Utility savings (\$) & & & & & & & & & & & \\
1 Bed, 1 Person & 225 & 232 & 239 & 247 & 255 & 264 & 274 & 285 & 297 & 309 & 2627 \\
1 Bed, 2 Person & 418 & 431 & 444 & 458 & 473 & 489 & 506 & 525 & 545 & 567 & 4856 \\
2 Bed, 2 Person & 418 & 431 & 444 & 458 & 473 & 489 & 506 & 525 & 545 & 567 & 4856 \\
2 Bed, 3 Person & 571 & 589 & 607 & 626 & 647 & 669 & 693 & 719 & 747 & 778 & 6646 \\
3 Bed, 3 Person & 571 & 589 & 607 & 626 & 647 & 669 & 693 & 719 & 747 & 778 & 6646 \\
3 Bed, 4 Person & 800 & 823 & 847 & 873 & 901 & 931 & 962 & 996 & 1033 & 1073 & 9239 \\
\hline
\end{tabular}

Table 3. Tenant utility savings as a function of market rent.

\begin{tabular}{|c|c|c|c|c|c|c|c|c|c|c|}
\hline Type & Year 1 & Year 2 & Year 3 & Year 4 & Year 5 & Year 6 & Year 7 & Year 8 & Year 9 & Year 10 \\
\hline \multicolumn{11}{|c|}{ Annual market rent (\$) } \\
\hline 1 Bed Apt. & 14,560 & 14,778 & 15,000 & 15,225 & 15,453 & 15,685 & 15,921 & 16,159 & 16,402 & 16,648 \\
\hline 2 Bed Apt. & 18,720 & 19,001 & 19,286 & 19,575 & 19,869 & 20,167 & 20,469 & 20,776 & 21,088 & 21,404 \\
\hline 3 Bed Apt. & 22,880 & 23,223 & 23,572 & 23,925 & 24,284 & 24,648 & 25,018 & 25,393 & 25,774 & 26,161 \\
\hline \multicolumn{11}{|c|}{ Annual utility savings (as a proportion (\%) of market rent) } \\
\hline 1 Bed, 1 Person & 1.54 & 1.57 & 1.59 & 1.62 & 1.65 & 1.69 & 1.72 & 1.76 & 1.81 & 1.86 \\
\hline 1 Bed, 2 Person & 2.87 & 2.91 & 2.96 & 3.01 & 3.06 & 3.12 & 3.18 & 3.25 & 3.32 & 3.41 \\
\hline 2 Bed, 2 Person & 2.23 & 2.27 & 2.30 & 2.34 & 2.38 & 2.42 & 2.47 & 2.53 & 2.58 & 2.65 \\
\hline 2 Bed, 3 Person & 3.05 & 3.10 & 3.15 & 3.20 & 3.26 & 3.32 & 3.39 & 3.46 & 3.54 & 3.63 \\
\hline 3 Bed, 3 Person & 2.50 & 2.53 & 2.57 & 2.62 & 2.66 & 2.71 & 2.77 & 2.83 & 2.90 & 2.97 \\
\hline 3 Bed, 4 Person & 3.50 & 3.54 & 3.60 & 3.65 & 3.71 & 3.78 & 3.85 & 3.92 & 4.01 & 4.10 \\
\hline
\end{tabular}

consumption rates. It also evident that operational utility expenses escalate at a marginally higher rate than the $\mathrm{CPI}^{6}$; therefore, it is to be expected that the NPV proposition of GB will be increasingly favourable over time.

Housing stress is attributed to households that spend more than $30 \%$ of their gross household income on accommodation expenses. By this definition, we can estimate the approximate contribution that GB certification may have on the overall housing stress of a household. In Figure 3, this margin has been visualized as the housing stress threshold', which will differ based on net household income. For the purposes of this study, we focus on the impact of GB certification, expressed as a percentage of market rent, for a typical building for low- and middle-income households in Brisbane, Australia.

Figure 3 introduces the concept of GB certification as a complementary aspect of existing government rental subsidies. NRAS provided a supply-side subsidy to investors to deliver reduced market rental costs for low- and middle-income households by 20\% (shown as 'AH Scheme'), although its relevance is applicable to international equivalents. The case study suggests that inclusion of GB certification into a hybrid GAH policy is expected to further reduce household rental costs by an indicative margin (shown as 'GB Scheme'). The level of additional benefit from a GB subsidy will vary by household size. For example, considering Year 1 of the economic modelling only, a one-person household would expect to receive a $21.54 \%$ reduction to their overall housing costs from both the government AH subsidy (NRAS in this example) and GB subsidy (utility efficiency).

While a 'GB Subsidy' is expected to deliver cost savings, an additional 'NRAS subsidy' (or rental subsidy) will be required to reduce housing costs to an affordable level in all modelled cases. Careful consideration is needed in order to balance issues of split-incentives and equitable distribution of the GB benefit to all key stakeholders (government, investors and tenants). Albeit, accurately measuring ongoing housing 


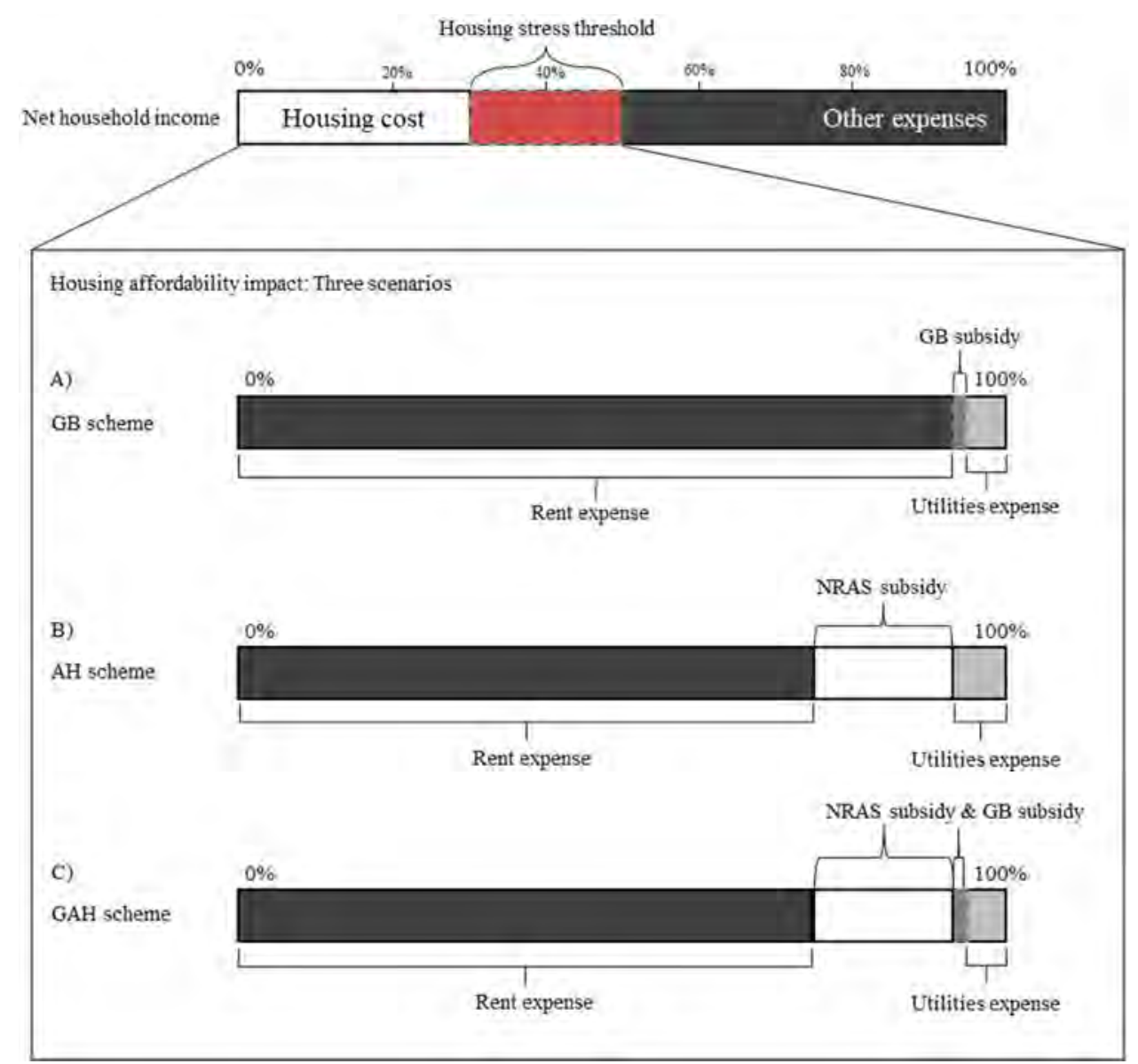

Figure 3. Housing expense and achievable savings.

stress of households within the scheme would not be without its challenges due to the variability in utility consumption between tenants.

Figure 4 illustrates the achievable savings from the GB case over a 10 -year period. As the figure suggests, rent comprises the bulk of household expenses for the sample. The GB utility savings represents the decrease in total housing costs compared to the BAU case over a 10 -year rental period.

GB reduced the total housing cost for tenants by $1.68 \%$ to $3.77 \%$ for the six household typologies examined in the case study analysis (i.e. one to four persons). As the literature suggests (Aimee, 2015; Chegut et al., 2016; Copiello, 2015; Deng \& $\mathrm{Wu}, 2014$ ), unlocking these long-term operational efficiency benefits comes a cost premium. The NPV of the anticipated green premium on construction cost has been analyzed in the next section.

\subsection{Net present value}

The case study analysis has determined that there is expected tangible operational savings directed to tenants occupying a GB; however, unlocking these savings will 


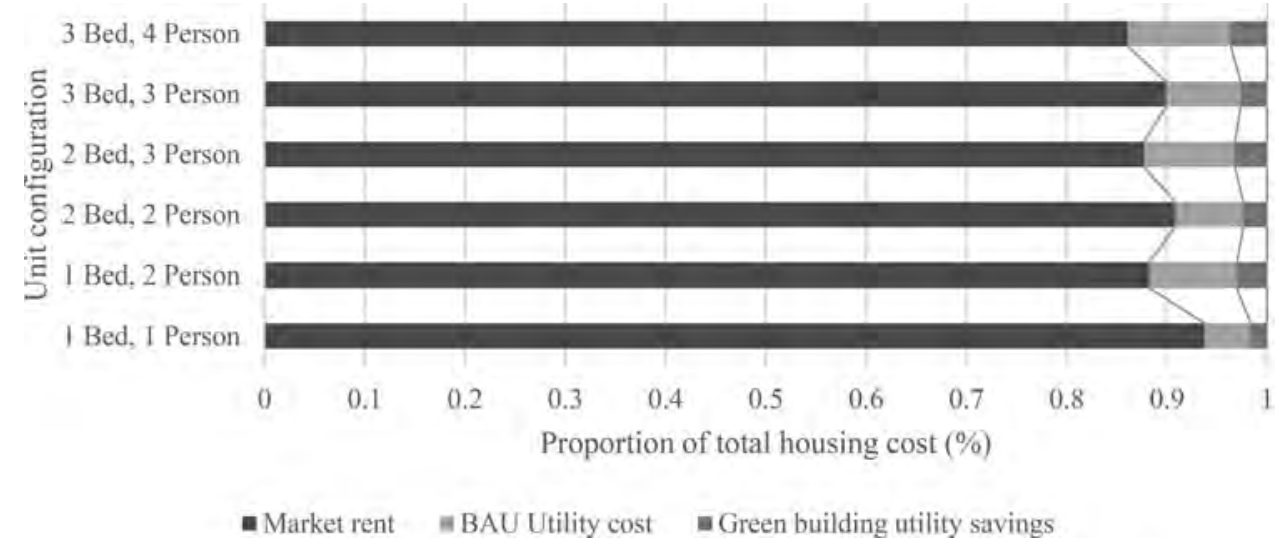

Figure 4. Total household expenditure ratio (10-year period).

likely require additional capital costs referred herein as the 'green premium' on construction cost. In this case study, the green premium is not capitalized into the market rent; therefore, the issues of split-incentives are nascent, particularly for the scheme investor. The NPV is the difference between the discounted value of all future cash flows derived from the operational utility savings as compared against the additional investment in terms of additional construction or capital costs. It therefore yields the net financial benefits. Theoretically, these benefits shall occur over the entire design life of the development (i.e. 50-100 years). It is beneficial to conduct an NPV analysis to understand how investment made in GB principles may yield value (net benefits) over time. The NPV analysis is beneficial to guiding government policy decisions on how, and to what degree a supply-side subsidy can be provided to investors.

A sensitivity analysis was conducted applying three green premium scenarios: (1) Low (1.5\%); (2) Medium (2.75\%); and (3) High (4\%) which are added to total construction cost. These scenarios were selected based on a sample of average comparable green rated multi-residential developments; 59 international and 30 domestic. The methodology supporting the three scenarios is outlined in S1.2 of the supplementary file, and in Table 1.

The NPV formula was applied considering a 10- and 20-year duration $(n=10,20)$ and a conservative discount rate of $5 \%$. The discount rate is an important aspect underpinning the overall cost-benefit assessment of any NPV calculation. A favourable investment (into GB or otherwise) should meet or exceed the normal rate of return available in comparable market segments (those which share similar risk characteristics). An NPV of $\$ 0$ indicates that investment into GB principles yields an average annual return of 5\% over the period. Morrissey et al. (2013) undertook an analysis to determine the appropriate discount rate for energy efficiency improvements in the Australian residential sector, taking into consideration economy-wide impacts such as carbon pricing considerations. A discount rate of $3.5 \%$ or lower was found to favour energy efficiency projects (Morrissey et al., 2013). A relatively conservative 5\% discount rate was selected for this study so that the analysis did not unfairly favour resource efficiency initiatives.

Meaningful utility escalation and discount rates are difficult to accurately estimate beyond a 20-year horizon, therefore a reduced NPV period was adopted. Consistency 
Table 4. NPV and IRR for green premium scenarios over 10- and 20-year periods.

\begin{tabular}{lccccc}
\hline $\begin{array}{l}\text { Green premium } \\
\text { cost over }\end{array}$ & $\begin{array}{c}\text { Green premium } \\
\text { on construction } \\
\text { BAU }(\%)\end{array}$ & $\begin{array}{c}\text { NPV green } \\
\text { premium }-10 \\
\text { years }(\$)\end{array}$ & $\begin{array}{c}\text { Internal rate of } \\
\text { return - 10 } \\
\text { years (\%) }\end{array}$ & $\begin{array}{c}\text { NPV green } \\
\text { premium - 20 } \\
\text { years }(\$)\end{array}$ & $\begin{array}{c}\text { Internal rate of } \\
\text { return }-20 \\
\text { years }(\%)\end{array}$ \\
\hline Low (1.5) & 290,250 & 72,461 & 10 & 404,560 & 17 \\
Mid (2.75) & 532,125 & $-157,897$ & -2 & 174,203 & 8 \\
High (4) & 774,000 & $-388,254$ & -8 & $-56,154$ & -4 \\
\hline
\end{tabular}

with typical NRAS tenures (i.e. 10 years) was also considered. The internal rate of return (IRR) was calculated for each scenario, as shown in Table 4.

Table 4 indicates that the NPV is sensitive to increases in the green premium on total construction cost (TCC) and the period of time used for NPV analysis. Considering utility savings over longer periods (i.e. $\geq 20$ years) diminishes most of the cost risk associated with the green premium on the TCC and improves the overall viability of GB initiatives. The NPV analysis suggests that a longer term horizon is favourable, particularly if green premium costs exceed $2.75 \%$. Lower green premium costs yield significant return. The results suggest that there is a strong value proposition supporting investment decisions towards GB standards. Government support is required to distribute these benefits equitably to both tenants and investors. We discuss three policy options in the following section.

\section{Discussion}

The case study findings suggest that 'greening' affordable housing (GAH) may offer positive net financial benefits when comparing the savings from utility costs against the additional capital or construction cost in the Australian case, and may be applied more broadly with applications internationally. The net financial benefits could even be higher if we consider for potential increases in residual value of the building (Chegut et al., 2016; Zhang et al., 2017) and plausible health and community benefits (Hu et al., 2014). This article contributes to the limited empirical analysis on this new topic of GAH within the Australian context. Consideration of a household's bottom line is an important factor in determining the 'affordability' of housing. While market rents comprise the bulk of housing-related expenses, utility bills are also substantial household expenditures and should receive greater consideration within future AH policy.

The study invokes a re-think to the way $\mathrm{AH}$ incentives are administered, through a combination of demand- and supply-side subsidies. Estimated weekly GB household savings of AUD\$5.05 to AUD\$17.76 (one- to four-person households, respectively) represent a form of demand-side subsidy, although is not solely anticipated to achieve the level of support delivered under current supply-side schemes such as NRAS. In the case of GAH policy, a conditional supply-side subsidy (conditional upon meeting GB standards or certification) will still be required in order to achieve adequate market rent discounts for low- and middle-income households; however, GB principles may be used to supplement these policies. Careful consideration will be required towards adequately addressing issues of split-incentives for investors into future supply-side GAH schemes, as investors will require a comparable rate of return given other options in the market. The NPV analysis has suggested that the net benefit of 
GB improvements are positive and therefore may offer a long-term value proposition as a system. In a scenario where green certification of housing stock within a GAH scheme is mandated, three policy options may be considered for policy makers:

1. Provision of a fixed income guarantee, or supply-side subsidy 'top-up' commensurate with market expectations on return. A portion of the green premium is capitalised into the investor incentive.

2. Implementation of a GB grant scheme to reduce or eliminate the green premium on construction cost.

3. Controversially, capitalisation of the green premium (or a portion of which) into the market rent. Caution is to be taken with formulating assumptions on utility savings as mentioned in the data limitations, there is often a mismatch of design and as-built operational performance savings due to a number of factors (i.e. occupant behaviour and envelope performance, among others). Application of this policy may worsen policy outcomes for some tenants as it would be forming an assumption on average utility use.

NRAS has been used as an example of a supply-side subsidy scheme in this article; however, the concepts discussed are anticipated to be transferable to international AH subsidy regimes (with regard to local conditions). From the broader context of governance, the inherent interconnectedness of political/social, environmental and economic objectives on improving social equality, COP carbon reduction commitments, and progressing the 'green economy' enhance the triple bottom line proposition of a future GAH policy. The NPV analysis conducted herein demonstrates the financial value of GB improvements to the 'system' on a 'per development' basis. However, at a macroeconomic level, GAH offers an alignment across a broader set of social and environmental objectives. A broad GAH scheme may serve as an enabler for the development of a robust GB economy - establishing demand for efficient and innovative construction practices, supply chains and developing national capacity towards 'greener' construction. While the seamless coupling and achievement of social and environmental targets are key elements of an overall GAH policy, this article was focused primarily on the economic/financial persuasion.

Through NRAS, financial incentives to private landlords and developers resulted in initial supply successes, yet ultimately failed to attract large-scale institutional investment into the sector. Bond-financed affordable housing delivery models, or, Housing Supply Bonds (HSB's) have been the primary focus of much of the literature, with a number of successful international examples applied in the United Kingdom, Austria and Switzerland (i.e. the Co-operative Swiss housing bond model and the Australian 'Housing Construction Convertible Bond' model (Lawson et al., 2009)). These models arguably offer better 'value for money' towards the issue (see Berry, 2003; Berry \& Hall, 2005; Lawson, 2014). Australian AH policy is entering a period of transition. In late 2017, the Australian treasury announced the roll out of an 'Australian Bond Aggregator Model' $^{7}$, with its foundations based in exemplar EU cases and academic research. With these changes, and a focus on government-backed bond financing 
models, GAH policy - which focuses on residential green certification (and the securitization of these assets) - is enhanced by the emerging demand for 'low-carbon' investments (i.e. Green Bonds). This represents an opportunity to channel a burgeoning 'Socially Responsible Investment' (SRI) portfolio from institutional investors towards the Australian AH problem. GAH housing serves to address the criteria of both social impact bonds and green bonds alike, and bond-based financing models generally offer the appropriate size, liquidity and risk-adjusted returns required by institutional investors- whose participation in future schemes is much needed. Examples have begun to emerge internationally. New York State, for example, issued a USD \$100 m Green Bond in 2016, with proceeds going directly into GAH housing (Coen, 2016). Certification measures serve to reduce the risk of 'green washing' underlying assets held within Green Bond issuances. Should an expansion of financing avenues translate into lower financing costs for GAH developments, the value proposition is further enhanced.

Beyond 'affordable' housing policy, it is important to note that the social housing stock remains largely undeveloped in Australia; accounting for only 4\% of all dwellings. This is in stark contrast to European countries with mature and well-funded social housing programs such as in Austria, Sweden and the UK, where net stock accounts for $25 \%, 20 \%$ and $18 \%$ of all dwellings, respectively, and $17 \%$ of all housing in the EU (Chegut et al., 2016; Pawson et al., 2018). A shift towards progressive GB policies in this early stage of development in the Australian affordable and social housing sector presents the country with a unique opportunity to ensure that future construction captures the benefits of superior operational utility efficiency.

\section{Conclusion}

Over the past decade, declining housing affordability in Australia, and much of the developed world, continues to affect an increasing number of households each year. Escalating residential gas, electricity and water prices compound the issue, further increasing housing costs. Collectively, these issues exacerbate affordability issues for low- and middle-income rental households.

In this article we have introduced the notion of capitalizing on GB principles, and the associated utility savings, as a demand-side subsidy to low- and middle-income households. We propose that an innovative GAH policy may offer a solution for mitigating the issues of split-incentives - delivering value for both tenants and investors, and ultimately delivering net benefits to government though wider environmental, economic and social considerations. We present a quantitative estimate of household utility savings through a case study of a Green Star multi-unit residential social housing development in Brisbane, Australia. Acknowledging study data limitations, rental households were estimated to save an average of AUD\$5.05-AUD\$17.76 (one- to four-person households respectively) on weekly utility costs. Aggregating annual utility savings over a 10-year tenancy arrangement reduced the total rental housing cost by $1.68-3.77 \%$, thereby enhancing the objectives of a NRAS-type scheme. The NPV analysis of the case study showed that developments are sensitive to a high 'green premium' on construction costs; however, a positive NPV was calculated for all 
longer term green premium scenarios examined. Low- and middle-income households benefit from long-term savings through reduced utility bills, further enhancing housing affordability outcomes and hedging against future utility price increases. Overall, the findings support the case for GAH policy in Australia and more broadly, offer synergies applicable to supply-side AH policy internationally.

Designing GAH policy that will attract Socially Responsible Investment (SRI) from large institutional investors is an important consideration. As the demand for 'green' asset classes grow internationally (CBI, 2018) there are emerging opportunities to capitalize on bond-based financing models which finance a pool of underlying greencertified affordable housing assets.

The design of future policy is recommended to consider an incentive structure that rewards superior operational performance of rental stock provided to low- and middle-income households, while meeting investor expectations on return. Broadly, the intent of these incentives may empower low- and middle-income households with equal opportunity for access to operationally efficient homes, achieving equitable amenity, operational comfort and building performance, to those benefited by many homeowners. The evidence provided in this article suggests that GB investments can offer enhanced building lifecycle operational efficiency in a cost-effective manner. Having said that, government support is required to meet market rent discounts comparable to existing supply-side schemes such as NRAS in Australia and similar schemes internationally.

Further research is required to create comprehensive GAH policy; three policy options are provided in this article as a starting point. Consideration of key stakeholders, their interactions and key performance indicators are required to develop effective policy measures. In particular, an understanding of innovative financing avenues, such as green, and social impact bonds, and their impact on AH policy outcomes is needed in the Australian context. While GAH development is not a panacea, it remains a step towards improving overall housing affordability outcomes for low- and middle-income households.

\section{Notes}

1. Demand-side assistance provides support to low-income tenants, either in the form of cash payments or housing vouchers.

2. Supply-side assistance provides government funding for the expansion of dwelling stock provided at less than market rates to eligible residents (Berry, 2005).

3. The total incentive value as of the 2016/2017 financial year is $\$ 11,048$ AUD per dwelling.

4. In accordance with the 'Building Code of Australia'(BCA) guidelines BCA. (2016) National Construction Code Australian Housing Industry Association.

5. Projects of comparable use, location, age, and Green star rating (where applicable) were favoured in the data set (i.e. utility consumption data from a comparable apartment building in a cooler climate (Melbourne) would not be applicable to that of an apartment building in a warm/temperate climate (Brisbane)).

6. The RBA's target inflation rate is $2-3 \%$ RBA. (2016) Target Inflation Rate. Available at: http://www.rba.gov.au/inflation/.

7. The Australian Bond Aggregator Model will be administered via a newly established 'National Finance and Investment Corporation' (NHFIC). The NHFIC will have an independent Board responsible for distributing loans to Australian community housing 
providers (CHPs) for the expansion of affordable housing stock. CHPs will benefit from a reduction in financing costs versus traditional means. Seed capital supporting the NHFIC will be raised via the bond market, guaranteed by the Commonwealth (for more see Lawson https://www.ahuri.edu.au/policy/ahuri-briefs/bond-aggregator-model).

\section{Acknowledgements}

The authors are grateful for the generous support from the National Affordable Housing Consortium, and the Sustainable Living Infrastructure Consortium.

\section{Disclosure statement}

No potential conflict of interest was reported by the authors.

\section{Funding}

This study was supported by National Affordable Housing Consortium, and the Sustainable Living Infrastructure Consortium.

\section{Notes on contributors}

Stefen MacAskill is a PhD Candidate at Griffith University. He holds a Bachelor of Business and a Master of Urban \& Environmental Planning with first class honours. His research primarily focuses on green building and sustainable finance. He has several years professional work experiencewithin architectural engineering consultancy and project finance. Stefen specialises in connecting business fundamentals with sustainable building practices.

Rodney A. Stewart is a Professor of Engineering Management at Griffith University Gold Coast Campus. He also teaches within the Griffith School of Engineering in areas such as Project/Engineering/Construction/Environmental Management. He holds a $\mathrm{PhD}$ in the field of Engineering Management and a Bachelor of Engineering with first class honours. Professor Stewart conducts research and consultancy activities predominately in the following areas: (1) smart metering of water and energy activities; (2) urban water planning and management; (3) water conservation research; (4) infrastructure planning and management; (5) environmental management; (6) renewable energy and battery storage solutions for the electricity grid; and (7) engineering/project management. His research goal is to provide evidence-based research to inform best practice planning, engineering and management paradigms for urban built environments.

Eduardo Roca is currently Professor of Finance and Head of the Finance and Financial Planning Discipline of the Department of Accounting, Finance and Economics, Griffith Business School, Griffith University. His expertise is in the field of finance, particularly in the areas of international financial market integration and linkages, international portfolio diversification, and alternative investments encompassing socially responsible investment, housing investment, water investment, and carbon market investment.

Benjamin Liu is a Senior Lecturer of Finance within the Department of Accounting, Finance and Economics, Griffith Business School, Griffith University, Australia. Benjamin obtained a $\mathrm{PhD}$ in Finance at Monash University, Australia and a Master's degree (Distinction-the highest class) at Massey University, New Zealand. His expertise and research interests include the field of finance and investments, particularly in the areas of corporate finance and corporate governance, mortgage finance and housing related research, alternative investments, and global financial markets. 
$\mathrm{Oz}$ Sahin is a Senior Research Fellow at the School of Engineering and Built Environment. He holds a $\mathrm{PhD}$ in the field of climate change adaptation and vulnerability assessment and has worked on numerous research projects with a range of large interdisciplinary teams. His research interests include integrated decision support systems using coupled system dynamics and GIS modelling, BN modelling, multiple criteria decision analysis and operational research methods. He has strong skills in integrated systems modelling, particularly in systems dynamics modelling and coupling this with GIS to develop spatially explicit models.

\section{ORCID}

Stefen MacAskill (D) http://orcid.org/0000-0002-4404-1694

Oz Sahin (D) http://orcid.org/0000-0002-1914-5379

\section{References}

ABS (2016) Water Account Australia, Cat 4610.0 (Canberra: Australian Bureau of Statistics).

ABS (2018) ABS Survey of Housing Occupancy and Costs, Cat 4130.0 (Canberra: Australian Bureau of Statistics).

ACCC (2017) Retail electricity pricing inquiry (Canberra: Australian Competition and Consumer Commission).

AER (2015) Electricity Bill Benchmarks 2015 (Brisbane: Australian Energy Regulator).

AEMC (2015) Residential Electricity Price Trends 2015, EPR0044 (Canberra: Australian Energy Market Commission).

Aimee, R. A. (2015) Improving energy efficiency in private rented housing: Why don't landlords act? Indoor and Built Environment, 24, pp. 913-924. doi: 10.1177/1420326X15598821

Athuraliya, A., Roberts, P., \& Brown, A. (2012) Yarra Valley Water Residential Water Use Study, Volume 2, (Melbourne: Yarra Valley Future Water).

Apgar, W. C. Jr (1990) Which housing policy is best? Housing Policy Debate, 1, pp. 1-32.

BCA (2016) National Construction Code Australian Housing Industry Association (Canberra: Australian Building Codes Board).

Beer, A., Kearins, B. \& Pieters, H. (2007) Housing affordability and planning in Australia: The challenge of policy under neo-liberalism, Housing Studies, 22, pp. 11-24.

Beal, C., \& Stewart, R. A. (2011) South East Queensland Residential End Use Study: Final Report. Technical Report No. 47, Brisbane: Urban Water Security Research Alliance.

Berry, M. (2003) Why is it important to boost the supply of affordable housing in Australiaand how can we do it? Urban Policy and Research, 21, pp. 413-435.

Berry, M. \& Hall, J. (2005) Institutional investment in rental housing in Australia: A policy framework and two models, Urban Studies, 42, pp. 91-111.

Berry, S., Whaley, D., Davidson, K. \& Saman, W. (2014) Do the numbers stack up? Lessons from a zero carbon housing estate, Renewable Energy, 67, pp. 80-89.

Bird, S. \& Hernández, D. (2012) Policy options for the split incentive: Increasing energy efficiency for low-income renters, Energy Policy, 48, pp. 506-514.

Boerenfijn, P., Kazak, J. K., Schellen, L. \& van Hoof, J. (2018) A multi-case study of innovations in energy performance of social housing for older adults in the Netherlands, Energy and Buildings, 158, pp. 1762-1769.

Bradshaw, W., Connelly, E. F., Cook, M. R., Goldstein, J., \& Pauly, J. (2005) The Costs \& Benefits of Green Affordable Housing (Boston: New Ecology Incorporated).

Cai, Z., Yin, Y., Wennerstern, R., et al. (2013) From energy efficiency to integrated sustainability in housing development in China: A case study in a hot-summer/cold-winter zone in China, Journal of Housing and the Built Environment, 28, pp. 329-344.

Cao, M. \& Hickman, R. (2018) Car dependence and housing affordability: An emerging social deprivation issue in London? Urban Studies, 55, pp. 2088-2105. 
CBI (2018) Bond and climate change: State of the market 2018 (London: Climate Bonds Initiative).

Chegut, A., Eichholtz, P. \& Holtermans, R. (2016) Energy efficiency and economic value in affordable housing, Energy Policy, 97, pp. 39-49.

Chua, G. (2014) The cost of sustainability: Hopkins street affordable housing by xsquared architects. Available at https://www.architectureanddesign.com.au/news/the-cost-of-sustainabilityhopkins-street-affordab (accessed 20 February 2017).

Coen, A. (2016) N.Y. state plans $\$ 100 \mathrm{~m}$ in affordable housing green bonds, The Bond Buyer (New York, N.Y. 1982), pp. 1.

Copiello, S. (2015) Achieving affordable housing through energy efficiency strategy, Energy Policy, 85, pp. 288-298.

Corelogic, (2016) RP Database. Available at: https://www.corelogic.com.au/ (accessed 8 June 2016).

Czischke, D. \& van Bortel, G. (2018) An exploration of concepts and polices on 'affordable housing' in England, Italy, Poland and The Netherlands, Journal of Housing and the Built Environment, pp. 1-21. doi: 10.1007/s10901-018-9598-1

Dawkins, C. J. (2011) Exploring the spatial distribution of low income housing tax credit properties i(Washington, DC: U.S. Department of Housing and Urban Development).

Deng, Y. \& Wu, J. (2014) Economic returns to residential green building investment: The developers' perspective, Regional Science and Urban Economics, 47, pp. 35-44.

Diamond, R. \& McQuade, T. (2019) Who wants affordable housing in their backyard? An equilibrium analysis of low-income property development, Journal of Political Economy, 127, pp. 1063-1117. doi: $10.1086 / 701354$

DuBois, C. (2018) The Low-Income Housing Tax Credit (Washington, DC: Urban Institute).

Dwaikat, L. N. \& Ali, K. N. (2016) Green buildings cost premium: A review of empirical evidence, Energy and Buildings, 110, pp. 396-403.

EME (2016) Energy Made Easy Calculator. Available at https://www.energymadeeasy.gov.au/ (accessed 16 March 2016).

Eslake, S. (2013) Australian Housing Policy: 50 Years of Failure (Canberra: Parliament of Australia).

Galster, G. (1997) Comparing Demand-Side and Supply-Side Housing Policies: Sub-Market and Spatial Perspectives, Housing Studies, 12, pp. 561-577.

Gan, X., Zuo, J., Wu, P., et al. (2017) How affordable housing becomes more sustainable? A stakeholder study, Journal of Cleaner Production, 162, pp. 427-437.

GBCA (2010) Potable Water Calculator Guide: Green Star - Multi Residential V1 (Sydney: Green Building Council Australia).

GBCA (2013) The Value of Green Star - A Decade of Environmental Benefits (Sydney: Green Building Council Australia).

GBCA (2016) Green Star - Multi Unit Residential V1/Fact Sheet \& Business Case (Sydney: Green Building Council Australia).

GBCA (2016a) Green Star - Multi Unit Residential v1: Fact Sheet \& Business Case (Sydney: Green Building Council Australia).

GBCA (2016b) Green Star Financial Transparency (Sydney: Green Building Council).

Government Q (2018). National Rental Affordability Scheme (NRAS). Available at https:// www.qld.gov.au/housing/renting/rent-assistance/nras (accessed 10 March 2018).

Hamidi, S., Ewing, R. \& Renne, J. (2016) How affordable is HUD affordable housing? Housing Policy Debate, 26, pp. 437-455.

Harrison, C. \& Popke, J. (2011) Because you got to have heat": The networked assemblage of energy poverty in Eastern North Carolina, Annals of the Association of American Geographers, 101, pp. 949-961.

Hoffman, A. J. \& Henn, R. (2008) Overcoming the social and psychological barriers to green building, Organization \& Environment, 21, pp. 390-419.

Hu, H., Geertman, S. \& Hooimeijer, P. (2014) Green apartments in Nanjing China: Do developers and planners understand the valuation by residents? Housing Studies, 29, pp. 26-43. 
Huduser (2018). Green building in low-income housing tax credit developments. Available at https://www.huduser.gov/portal/pdredge/pdr_edge_featd_article_061614.html (accessed 12 March 2018).

Hwang, B. G. \& Tan, J. (2012) Green building project management: Obstacles and solutions for sustainable development, Sustainable Development, 20, pp. 335-349.

Islam, H., Jollands, M. \& Setunge, S. (2015) Life cycle assessment and life cycle cost implication of residential buildings-A review, Renewable and Sustainable Energy Reviews, 42, pp. 129-140.

Issa, M., Rankin, J. \& Christian, A. (2010) Canadian practitioners' perception of research work investigating the cost premiums, long-term costs and health and productivity benefits of green buildings, Building and Environment, 45, pp. 1698-1711.

Jacobs, K., Lawson, J., Gabriel, M. \& Hulse, K. (2015) Individualised and Market-Based Housing Assistance: Evidence and Policy Options, AHURI Final Report No.253 (Melbourne: Australian Housing and Urban Research Institute Limited).

Lawson, J., Berry, M., Milligan, V., et al. (2009) Facilitating investment in affordable housing Towards an Australian model, Housing Finance International, 24, pp. 18-25.

MacKillop, F. (2013) Sustainable as a basis of affordable? Understanding the affordability 'crisis' in Australian housing, Australian Planner, 50, pp. 2-12.

Mangold, M., Österbring, M., Overland, C., et al. (2018) Building ownership, renovation investments, and energy performance-A study of multi-family dwellings in Gothenburg, Sustainability, 10, pp. 1684.

McKenna, D. (2017) Cost premiums for green buildings in Qatar, QScience Connect, 2017, pp 1-17. doi: 10.5339/connect.2017.qgbc.5

Milligan, V., Gurran, N., Lawson, J., et al. (2009). Innovation in Affordable Housing in Australia: Bringing Policy and Practice for Not-For-Profit Housing Organisations Together, AHURI Final Report No.134 (Melbourne: Australian Housing and Urban Research Institute).

Moore, T., Nicholls, L., Strengers, Y., et al. (2017) Benefits and challenges of energy efficient social housing, Energy Procedia, 121, pp. 300-307.

Morrissey, J. \& Horne, R. E. (2011) Life cycle cost implications of energy efficiency measures in new residential buildings, Energy and Buildings, 43, pp. 915-924.

Morrissey, J., Meyrick, B., Sivaraman, D., et al. (2013) Cost-benefit assessment of energy efficiency investments: Accounting for future resources, savings and risks in the Australian residential sector, Energy Policy, 54, pp. 148-159.

National Housing Strategy (1992) National Housing Strategy Social Housing Workshop, Melbourne Report on outcomes of Social Housing Workshop (Canberra: National Housing Strategy).

Nikolaidis, Y., Pilavachi, P. A. \& Chletsis, A. (2009) Economic evaluation of energy saving measures in a common type of Greek building, Applied Energy, 86, pp. 2550-2559.

Oxley, M. (2004) Economics, Planning and Housing (London: Red Globe Press).

Oxley, M. (2012) Supply-side subsidies for affordable rental housing, in: S. J. Smith (Ed) International Encyclopedia of Housing and Home, pp. 75-80 (San Diego, CA: Elsevier).

Pawson, H., Parsell, C., Saunders, P., et al. (2018) Australian Homelessness Monitor 2018 (Melbourne: Launch Housing).

Lawson, J., Berry, M., Hamilton, C. and Pawson, H. (2014) Enhancing Affordable Rental Housing Investment via an Intermediary and Guarantee, AHURI Final Report No. 220 (Melbourne: Australian Housing and Urban Research Institute Limited).

Pero, A. S. D., Adema, W., Ferraro, V., et al. (2016) Policies to Promote Access to Good-Quality Affordable Housing in OECD Countries, pp. 82. (Canberra: OECD iLibrary).

QDC (2011) Queensland Development Code Mandatory Part 4.1 (Brisbane: Queensland Government Department of Housing and Public Works).

RBA (2016) Reserve Bank Australia - Target Inflation Rate. Available at http://www.rba.gov.au/ inflation/ (accessed 2 May 2016). 
Rehm, M. \& Ade, R. (2013) Construction costs comparison between 'green' and conventional office buildings, Building Research \& Information, 41, pp. 198-208.

Reina, V. J. \& Kontokosta, C. (2017) Low hanging fruit? Regulations and energy efficiency in subsidized multifamily housing, Energy Policy, 106, pp. 505-513.

Rawlinsons. (2016) Rawlinsons Australian Construction Handbook (Perth: Rawlinsons Publishing).

Rowley, S., James, A., Gilbert, C., Gurran, N., Ong, R., Phibbs, P., Rosen, D. and Whitehead, C. (2016). Subsidised Affordable Rental Housing: Lessons from Australia and Overseas, AHURI Final Report No. 267, (Melbourne: Australian Housing and Urban Research Institute).

Sa-Aadu, J. (1984) Another look at the economics of demand-side versus supply-side strategies in low-income housing, Real Estate Economics, 12, pp. 427-460.

Schwartz, H. L., Curtright, A. E., Ogletree, C., et al. (2018) Energy Efficiency as a Tool for Preservation of Affordable Rental Housing: Evaluation of the Efficiency Emphasis in the MacArthur Foundation's Window of Opportunity Initiative (MacArthur Foundation; RAND).

Shirgaokar, M. \& Rumbach, A. (2018) Investigating housing tenures beyond homeownership: A study of informal settlements in Kolkata, India, Housing Studies, 33, pp. 117-139.

Swoboda, K. (2013) Energy Prices - The Story Behind Rising Prices. Commonwealth of Australia (Canberra: Parliament of Australia).

Urban Utilities. (2016) Residential Water and Sewerage Charges 2016-2017 (Brisbane: Queensland Urban Utilities).

Verbeeck, G. \& Hens, H. (2005) Energy savings in retrofitted dwellings: Economically viable? Energy and Buildings, 37, pp. 747-754.

Walls, M., Gerarden, T., Palmer, K. \& Bak, X. F. (2017) Is energy efficiency capitalized into home prices? Evidence from three U.S. cities, Journal of Environmental Economics and Management, 82, pp. 104-124.

Wiley, J. A., Benefield, J. D. \& Johnson, K. H. (2010) Green design and the market for commercial office space, The Journal of Real Estate Finance and Economics, 41, pp. 228-243.

Wilkins, R. L. \& Inga, (2018) The Household, Income and Labour Dynamics in Australia Survey: Selected Findings from Waves 1 to 16, pp. 150. (Melbourne Institute: Applied Economic \& Social Research).

Willis, R. M., Stewart, R. A., Giurco, D. P., Talebpour, M. R., \& Mousavinejad, A. (2013) End use water consumption in households: Impact of socio-demographic factors and efficient devices. Journal of Cleaner Production, 60, pp. 107-115.

Wrigley, K. \& Crawford, R. H. (2017) Identifying policy solutions for improving the energy efficiency of rental properties, Energy Policy, 108, pp. 369-378.

Yates, J. (2008) Australia's housing affordability crisis, Australian Economic Review, 41, pp. 200-214.

Yates, J. \& Whitehead, C. (1998) In defence of greater agnosticism: A response to galster's 'comparing demand-side and supply-side housing policies', Housing Studies, 13, pp. 415-423.

Yudelson, J. (2008) The Green Building Revolution (Washington, DC: Island Press).

Zalejska-Jonsson, A., Lind, H. \& Hintze, S. (2012) Low-energy versus conventional residential buildings: Cost and profit, Journal of European Real Estate Research, 5, pp. 211-228.

Zhang, Y., Grant, A., Sharma, A., Chen, D., \& Chen L. (2009) Assessment of rainwater use and greywater reuse in high-rise buildings in a brownfield site. Water Science \& Technology, 60, pp. $575-581$.

Zhang, L., Liu, H. \& Wu, J. (2017) The price premium for green-labelled housing: Evidence from China, Urban Studies, 54, pp. 3524-3541.

Zhang, L., Wu, J. \& Liu, H. (2018) Policies to enhance the drivers of green housing development in China, Energy Policy, 121, pp. 225-235. 